\title{
Corporate Brand Personality and Personal Branding Procedures in Non - Profit Organization
}

\author{
Chuenjit Changchenkit
}

\begin{abstract}
Personal Branding plays an important role in Corporate Branding. The organization in this research is a non profit governmental based organization, providing database to other government agencies and public. Qualitative method was employed in this research by focus group and in - depth interview with personnel in the organization. The objectives were to construct the personal branding procedures from prior survey result of corporate brand personality and corporate personality traits and suggest tools for the organization's implementation. The result showed that personal branding procedures were set into four steps. First, personnel self assessment form design to let people evaluate their own strengths and weaknesses. Second, value-added projects creation to show agile and collaborative working style. Third, personality grooming to bring people image from personality traits of sincerity, excitement, and ruggedness. Finally, projects evaluation by Net Promoter Score method to measure the projects referral by stakeholders. It was recommended that internal marketing strategy should be implemented to promote people's inner trust and pride in themselves and organization.
\end{abstract}

Index Terms-Corporate brand personality, corporate personality raits, personal branding, non-profit organization.

\section{INTRODUCTION}

Personal branding has been implemented pervasively for people in many institutions and organizations, not only for the celebrities. Such organizations as big corporates like Microsoft or even small enterprises can employ the personal branding strategy to enhance the unique image of the organizations. When combining the emotional appeal to personal branding development, it can help the organization to define ideal audience or target group. Personal branding should be created to specific target customers [1]. Corporate branding story can be told through a personal brand, making more trust with the audience, a distinct voice, a difference from the competitors, an extended reach, and lasting power to stakeholders [2]. Besides, personal brand and corporate brand should be connected to each other in a term of character or personality and mission [3]. Therefore, personal branding should relate to corporate brand personality.

For the organization in this empirical research, the organization, namely $\mathrm{X}$, is a non - profit governmental based organization, providing database to other government agencies and public. Corporate brand vision has been set to create value to stakeholders and make them satisfy through service excellence. One of the key success factors is people in this organization. Personal branding is, therefore, a strategic

Manuscript received November 2, 2018; revised March 3, 2019.

Chuenjit Changchenkit is with the Kasetsart University, Bangkok, Thailand (e-mail: fbuscjc@ku.ac.th). tool to enhancing corporate brand equity. However, personal branding should be connected to the corporate brand personality to create a unique corporate image and build trust to customers and stakeholders.

From prior research survey in the year of 2017, corporate brand personality was found in the action type, working with agility and collaboration. Corporate personality traits were sincerity, excitement, and ruggedness. All of this input were formulated in the personal branding strategy.

The research question is that how this non-profit government agency can make people as a brand to support their corporate brand strength. The research contribution is to define the personal branding procedures for the organization in the study with corporate brand personality connection.

This research is, therefore, to study the personal branding procedures for the organization and give some specific tools to each step of the personal branding procedures. The organization $\mathrm{X}$ can implement the tools to enhance brand equity from giving value to society and customers. The key elements to clarify their corporate brand personality are active performance, collaborating with both inside the organization and outside the organization and reflecting the identity of sincerity, excitement and ruggedness.

\section{LITERATURE REVIEW}

\section{A. Personal Branding}

Personal branding is the process to make individuals and entrepreneurs differentiate from others by identifying and articulating their unique value propositions, whether professional or personal, and then leverage it across platforms with a consistent message and image to achieve specific goals [4]. The three key elements for effective personal branding are personal value statement identification, making a plan to differentiate personal brand and creating a powerful marketing plan.

There are four steps for personal branding strategy [4]:

Sep 1: Discover your brand, by identifying strengths and weaknesses for each individuals and let them make a common personal value statement for the organization.

Step 2: Create your brand, by elaborating the expertise from the personal value propositions statement. By combining the corporate personality to people expertise can drive target audiences to perceive and build trust to the personal brand.

Step 3: Communicate your brand, selecting contact points to target audience, both online and offline marketing communication. The goal is to make a word- of- mouth communication, thus, drawing people say about or even aware 
of the personnel in the organization.

Step 4: Maintain your brand, keep monitoring the referral communication about personal branding of the organization. Besides, let people share the news or information from your brand. Keep good relationship to stakeholders making them your network.

\section{B. Corporate Brand Personality}

Corporate brand personality can be defined in terms of the human characteristics or traits of the employees of a corporation as a whole, reflecting the values, words, and actions of employees and management in the organization [5]. The corporate brand personality comprises of three components. First, feeling or values factor, which show employees' working in passion and compassion style. Second, thoughts or words factor, which signify staff's creativity and disciplines in organizing job. Third, action factor, illustrating working style of employees in proactive or agile action and collaborative working team to support customers and all of stakeholders. Besides, corporate brand personality design is a process from inside to outside organization to create a brand associations with target audiences. Corporate brand personality can be reflected to employees personality [6].

\section{Corporate Personality Traits}

Corporate brand personality can be defined in terms of the human characteristics associated with a brand [7].

Corporate personality traits, signifying corporate brand identity, have been classified in five categories [7];

1. Sincerity: down to earth, honest, wholesome and cheerful.

2. Excitement: daring, spirited, imaginative and up-to-date.

3. Competence: reliable, intelligence and successful.

4. Sophistication: upper class and charming.

5. Ruggedness: outdoorsy and tough.

Corporate personality traits can present the appearance or look of people in the organization. The corporate brand identity, therefore, has been drawn from corporate personality traits.

\section{Result of Corporate Branding Survey of Organization} $X$ in the year of 2017

The organization $\mathrm{X}$ conducted a survey to study corporate brand personality perception and corporate brand identity, reflected from corporate brand personality traits in the year of 2017. Descriptive research were employed in this study. Samples were from internal personnel, that is, 16 executives and 24 staffs from various departments, and outside stakeholders, that is, 60 customers. Most of the customers were users in other government agencies. Purposive sampling had been identified to gather the data. Data analysis had been done through frequency, percentage, and mean score.

The result of overall corporate brand personality perception was shown in Table I.

From Table I, result showed that corporate brand personality of organization had been perceived in a high level, especially in the element of action type. If this organization were a man, he would be an active man, working with agility and collaborating their jobs well with others. Besides, the survey had been done to analyze corporate brand identity from corporate personality traits. Findings were summarized in Table II.

TABle I: Overall CoRPorate BRAND PERSONALity PERCEPTION TOWARDS ORGANIZATION $\mathrm{X}$

\begin{tabular}{|c|c|c|}
\hline Corporate Brand Personality & Mean & Level of Perception \\
\hline 1. Feelings or Value Factors & 3.82 & High \\
\hline 1.1 Passion on work Accomplishment & 4.00 & High \\
\hline $\begin{array}{l}1.2 \text { Compassion to do things for } \\
\text { others }\end{array}$ & 3.69 & High \\
\hline 2. Thoughts or Words Factors & 3.89 & High \\
\hline 2.1 Creativity in work design & 3.84 & High \\
\hline 2.2 Disciplines or regulations & 3.86 & High \\
\hline 3. Action Factors & 3.99 & High \\
\hline 3.1 Agility or proactive working & 3.98 & High \\
\hline 3.2 Collaborative working with others & 4.12 & High \\
\hline
\end{tabular}

TABLE II: CORPORATE B RAND IDENTITY OF ORGANIZATION X

\begin{tabular}{|l|c|c|}
\hline Corporate Personality Traits & Mean & Level of Perception \\
\hline 1. Sincerity & $\mathbf{4 . 0 5}$ & High \\
1.1 Down-to-earth & 3.72 & High \\
1.2 Honest & 4.32 & High \\
1.3 Wholesome & 4.21 & High \\
1.4 Cheerful & 3.97 & High \\
\hline 2. Excitement & $\mathbf{3 . 9 1}$ & High \\
2.1 Daring & 3.65 & High \\
2.2 Spirited & 4.03 & High \\
2.3 Imaginative & 3.87 & High \\
2.4 Up-to-date & 4.03 & High \\
\hline 3. Competence & $\mathbf{3 . 6 7}$ & High \\
3.1 Reliable & 3.93 & High \\
3.2 Intelligent & 3.93 & High \\
3.3 Successful & 3.84 & High \\
\hline 4. Sophistication & $\mathbf{3 . 5 8}$ & High \\
4.1 Upper Class & 3.65 & High \\
4.2 Charming & 3.50 & High \\
& & \\
\hline 5. Ruggedness & & High \\
5.1 Outdoorsy & $\mathbf{3 . 8 1}$ & High \\
5.2 Tough & 3.95 & 3.65 \\
\hline
\end{tabular}

From Table II, it was noted that all of corporate personality traits had been perceived in a high level. The top three of highest mean score were in the type of sincerity, excitement and ruggedness, with means score of 4.05, 3.91 and 3.81, respectively.

Such prior survey result had been used to formulate personal branding procedures of organization $\mathrm{X}$ and give some specific tools to each step of the personal branding procedures.

\section{Methodology}

The research approach is qualitative method. Data collection has been done through secondary source and primary source.

1. Secondary source of data included research report on corporate brand personality and corporate personality traits of organization X, done in the year of 2017. The samples were collected by survey method from internal personnel, that is, 16 executives and 24 staffs from various department, and outside stakeholders, that is, 60 customers. Research articles about personal branding and corporate personality branding were employed in this research, as well. 
2. Primary source of data has been gathered by in-depth interview and focus group with 25 informants in the organization X, 5 persons from management team and 20 persons from operational staff. The informants were qualified from those who have worked in this organization for at least 2 years, from front line and back line functions. The determined outcome from this qualitative method was the personal branding procedures for this organization.

After data were all collected, researcher had set the tools for each step of personal branding procedures, consisting of four steps, as mention earlier.

\section{RESUlt AND DisCUSSION}

\section{A. Personal Branding Procedures of Organization $X$}

From Table III, procedures to construct a personal branding strategy, reflecting corporate brand personality and identity for organization X, were identified into 4 steps. Each had its own mechanism but relating to each other. First, discover people's brand. The process for this step was to let staff evaluate themselves and found what were their strengths and weaknesses. Then, create their own brand through project planning which could enhance the corporate brand personality in the action type. Next, communicate the things they had done through the communication plan, both online and offline media to reflect people's identity from personality traits of sincerity, excitement and ruggedness. Finally, measure the outcome periodically and evaluate the personal branding project referral via Net Promoter Score or NPS.

The NPS measurement tool has been used pervasively recently by constructing simple questions whether the respondents would recommend the projects to their peers or not. The scale using in NPS ran from zero to ten. If the respondents would like to definitely recommend the projects to others, they could select the number of ten, if not it could be zero. Those who select the number of nine and ten are called promoters. While, those who choose the number of seven and eight are called passives. Besides, those who gave zero to six are detractors. NPS score could be calculated by percentage of promoters minus by percentage of detractors.

TABLE III: PERSONAL BRANDING PROCEDURES OF ORGANIZATION X

\begin{tabular}{|c|c|c|c|}
\hline $\begin{array}{c}\text { Personal } \\
\text { Branding Step }\end{array}$ & Procedures Determination & Tool & KPI \\
\hline $\begin{array}{l}\text { 1.Discover } \\
\text { Your Brand }\end{array}$ & $\begin{array}{l}\text { 1.1 Personnel evaluate their own Strengths and weaknesses. } \\
\text { 1.2 Strength and Weakness : Self Assessment Form was developed from corporate brand } \\
\text { personality and identity. } \\
\text { If staff thought Corporate brand personality could reflect themselves in the action type and } \\
\text { explained their own personality traits as sincerity, excitement and ruggedness, it would be their } \\
\text { strength to have personality and identity that related to corporate brand personality and } \\
\text { personality traits. If not, it would be their weakness in that part. }\end{array}$ & $\begin{array}{l}\text { Self Assessment } \\
\text { Form (See in } \\
\text { Table IV and V) }\end{array}$ & $\begin{array}{l}\text { Self Assessment } \\
\text { Form Completion } \\
\text { Rate }\end{array}$ \\
\hline $\begin{array}{l}\text { 2.Create Your } \\
\text { Brand }\end{array}$ & $\begin{array}{l}\text { 2.1 Create projects that could employ the expertise of the organization } \mathrm{X} \text {. } \\
\text { 2.2 Staffs should organize the projects to show their own talents and reflect corporate brand } \\
\text { personality } \\
\text { 2.3 Make a marketing plan of personal branding projects }\end{array}$ & $\begin{array}{l}\text { Action Plan for } \\
\text { personal } \\
\text { branding } \\
\text { projects. (See in } \\
\text { Table VI) }\end{array}$ & $\begin{array}{l}\text { Number of } \\
\text { projects } \\
\text { implementation. }\end{array}$ \\
\hline $\begin{array}{l}\text { 3.Communicate } \\
\text { Your Brand }\end{array}$ & $\begin{array}{l}\text { 3.1 Select contact points to communication about personal branding projects. } \\
\text { 3.2 Make a decision about a proper budget between online and offline communication. } \\
\text { 3.3 Staff's personality grooming to reflect corporate personality traits of sincerity, excitement, } \\
\text { and ruggedness. } \\
\text { 3.4 Make a Word of Mouth communication and let people say about or aware of people in the } \\
\text { organization X. }\end{array}$ & $\begin{array}{l}\text { Communication } \\
\text { Plan (See in } \\
\text { Table VI) }\end{array}$ & $\begin{array}{l}\text { Number of } \\
\text { projects } \\
\text { implementation }\end{array}$ \\
\hline $\begin{array}{l}\text { 4.Maintain } \\
\text { Your Brand }\end{array}$ & $\begin{array}{l}\text { 4.1 Measure the outcome from the personal branding projects, whether they could accomplish } \\
\text { the goal in the plan or not. } \\
4.2 \text { Measure up the personal branding project referral, by using Net Promoter Score or NPS }\end{array}$ & $\begin{array}{l}\text { Net Promoter } \\
\text { Score or NPS }\end{array}$ & $\begin{array}{l}\text { Net Promoter } \\
\text { Score or NPS }\end{array}$ \\
\hline
\end{tabular}

\section{A. Tools for Personal Branding Procedures}

Researcher had constructed the tools for each step of personal branding procedures by workshop focus group and in-depth interview. Tools were explained as follows,

\section{1) Self Assessment Form}

Self Assessment Form for people in the organization $\mathrm{X}$ consisted of three parts;

1.1 Personal Brand Personality: Value, Words and

\section{Actions}

1.2 Personal Brand Identity or Personality Traits:

Sincerity, Competence, Excitement, Sophistication and Ruggedness

1.3 Demographic Factors: Gender, Age, Income,

Number of working year in organization X,

And Education

The Example of Self Assessment Form was shown in Table IV and Table V. 
Part 1: Answer the following questions that match your opinion about your personal personality.

TABLE IV: PERSONAL BRAND PERSONALITy SELF ASSESSMENT OF ORGANIZATION X

\begin{tabular}{|c|c|c|c|c|c|}
\hline \multirow[t]{2}{*}{ Personal Brand Personality } & \multicolumn{5}{|c|}{$\begin{array}{c}\begin{array}{c}\text { Level of } \\
\text { Agreement }\end{array} \\
\text { Strongly Agree- } \\
\text { Strongly Disagree }\end{array}$} \\
\hline & 5 & 4 & 3 & 2 & 1 \\
\hline $\begin{array}{l}\text { 1. Value or Feelings Dimension } \\
\text { 1.1 My working goal is to support the organization } \\
\text { to be the leader in the industry. }\end{array}$ & & & & & \\
\hline $\begin{array}{l}1.2 \text { I wish me myself to be a key person to make a } \\
\text { success in the organization } X \text {. }\end{array}$ & & & & & \\
\hline $\begin{array}{l}1.3 \text { I wish to be a brand ambassador of the } \\
\text { organization } \mathrm{X} \text {. }\end{array}$ & & & & & \\
\hline $\begin{array}{l}\text { 1.4 I always do my best to serve customers or } \\
\text { stakeholders. }\end{array}$ & & & & & \\
\hline 1.5 I dedicate myself for the sake of organization $\mathrm{X}$. & & & & & \\
\hline $\begin{array}{l}\text { 1.6 I always involve in any activities like corporate } \\
\text { social responsibility of organization } X\end{array}$ & & & & & \\
\hline $\begin{array}{l}\text { 2. Words or Thoughts Dimension } \\
2.1 \text { I always use creativity in work or solve any } \\
\text { problems. }\end{array}$ & & & & & \\
\hline $\begin{array}{l}2.2 \text { I work with innovative idea to make the } \\
\text { organization } \mathrm{X} \text { be a value - driven organization. }\end{array}$ & & & & & \\
\hline $\begin{array}{l}2.3 \text { My creativity always contributes to the } \\
\text { organization success in value-added offering to } \\
\text { stakeholders. }\end{array}$ & & & & & \\
\hline $\begin{array}{l}\text { 2.4 I work accordingly to the regulations or rules of } \\
\text { organization X strictly. }\end{array}$ & & & & & \\
\hline 2.5 I set my goal from the organization's goal. & & & & & \\
\hline $\begin{array}{l}2.6 \text { I work accordingly to corporate mission, which } \\
\text { is the guide line to success for every persons. }\end{array}$ & & & & & \\
\hline $\begin{array}{l}\text { 3. Action Dimension } \\
\text { 3.1 I always do a proactive job and make an idea to } \\
\text { differentiate our organization. }\end{array}$ & & & & & \\
\hline 3.2 I eager to work and receptive to change & & & & & \\
\hline $\begin{array}{l}3.3 \text { I wish my organization to be the leader in this } \\
\text { industry. }\end{array}$ & & & & & \\
\hline 3.4 I collaborate my job to others for success. & & & & & \\
\hline $\begin{array}{l}3.5 \text { I can work as a team to get job done and solve } \\
\text { problems. }\end{array}$ & & & & & \\
\hline $\begin{array}{l}\text { 3.6 I Teamwork is more important than individual's } \\
\text { core competencies }\end{array}$ & & & & & \\
\hline
\end{tabular}

Part 2: Answer the following questions that reflect your personality traits or identity.

TABLE V: PERSONAL BRAND IDENTITY ASSESSMENT OF ORGANIZATION X

\begin{tabular}{|l|c|c|c|c|c|}
\hline \multirow{2}{*}{ Personal Brand Identity } & \multicolumn{5}{c|}{ Level of Agreement } \\
& \multicolumn{2}{|c|}{ Strongly Agree } & \multicolumn{3}{c|}{ Strongly Disagree } \\
\hline & 5 & 4 & 3 & 2 & 1 \\
\hline 1. Down-to-earth & & & & & \\
\hline 2. Honest & & & & & \\
\hline 3. Wholesome & & & & & \\
\hline 4. Cheerful & & & & & \\
\hline 5. Daring & & & & & \\
\hline 6. Spirited & & & & & \\
\hline 7. Imaginative & & & & & \\
\hline 8. Up-to-date & & & & & \\
\hline 9. Reliable & & & & & \\
\hline 10.Intelligent & & & & & \\
\hline 11.Successful & & & & & \\
\hline 12.Upper Class & & & & & \\
\hline 13.Charming & & & & & \\
\hline 14.Outdoorsy & & & & & \\
\hline 15.Tough & & & & & \\
\hline
\end{tabular}
Source: Adapted from [7]

Part 3: Demographic factors
1. Gender
Female

2. Age

$\square \quad 21$ - 30 yrs old $\square 31$ - 40 yrs old

3. Income ...............USD/month

4. Education $\square$ Bachelor Degree $\square$ Master Degree Doctoral Degree

\section{2) Personal branding projects}

Now, each person in the organization could understand their own strengths and weaknesses from the assessment. It was noted that corporate brand personality was in the action type, working with agility and collaboration. Therefore, those who gained higher score in the action dimension of personal brand personality would have strength and could represent the corporate brand personality's strength. Prior results showed that the corporate personality traits or corporate brand identity were sincerity, excitement and ruggedness. Those staff who showed themselves identifying such identities would be those who reflected corporate identity over themselves. These people could be the think tank of the organization who created the projects employing the expertise of the organization $\mathrm{X}$. Then, the staff should communication the projects to stakeholders with sincerity, excitement and ruggedness style.

The projects were initiated and implemented by staff in the organization X. These could create personal branding for staff in the organization $\mathrm{X}$ and communicate their own brand through various forms of contact points, as shown in Table VI.

TABLE VI: The Action Plan For Personal BRANDing Projects of ORGANIZATION X

\begin{tabular}{|l|l|l|l|l|l|l|l|l|l|l|l|l|}
\hline \multicolumn{1}{|c|}{ Project and } \\
Communication
\end{tabular}

From Table VI, researcher proposed the action plan for personal branding projects of organization $\mathrm{X}$, including media or contact points plan as shown in the Table VI.

2.1 Conference held by the Organization $\mathrm{X}$ :

Detail: The unique event that would make a showcase in data implementation for key decision in the country. CEO of the organization $\mathrm{X}$ and management team would hold a panel discussion on current issue in the country. Successful showcase using data from the organization $\mathrm{X}$ to make a 
decision in problem solving were elaborated in the event, as well.

Contact Points: Event Marketing for one day, unique session organized by organization $\mathrm{X}$.

\subsection{Students' Talent Program:}

Detail: The organization $\mathrm{X}$ would invite students from universities to have one day visit at the head office of organization $\mathrm{X}$. The marketing team of organization $\mathrm{X}$ may send out caravan team to various universities to invite students for applying to Students' Talent Program during the summer holiday for students' internship. Those who gained the top scores in class and job appraisal would be awarded by the organization $\mathrm{X}$.

Contact Points: Event Marketing as well as, Social Media.

2.3 News Updated:

Detail: Organization X would make a content marketing, including news and clip associated with consumers' daily lifestyle.

Such social media as Facebook, line twitter and Instagram were used to tell the organization's story, naming the name of social media channel of Organization $\mathrm{X}$ news, for example. The objective of this activities was to build brand awareness from the social media channel.

Contact Points: Social media such as Facebook, line, twitter, Instagram.

\section{4 "Do it Make it" Campaign.}

Detail: Organization $\mathrm{X}$ would set a program on social media explaining how information from this organization would be beneficial to the country and society. The announcers of the programs were staff of the organization $\mathrm{X}$, presenting in a sincerity, excitement and ruggedness personality.

Contact Points: Social media such as Facebook, line, twitter, Instagram and users' generated content.

\section{5 "I Can Do" Campaign}

Detail: Human resource department of the organization $\mathrm{X}$ would initiate program to promote internal marketing inside of the organization. Many workshops had been raised to train people to do something not directly related to the work, for example, short movie making workshop, public speaking workshop, etc. All of these would make them see their inside valuable capabilities.

Contact Points: Event Marketing for inside the organization X, poster, etc.

\section{Net Promoter Score}

The last step in personal branding was to measure the outcome from the personal branding projects, whether they could accomplish the goal in the plan or not. Besides, researcher had elaborated the tool from workshop in focus group and in - depth interview to measure up the personal branding project referral, by using Net Promoter Score or NPS since NPS could evaluate customers and stakeholders' loyalty by asking them questions about their intention to refer the brand or the projects to others[8]. Steps for NPS were as follows:

3.1 Invite the customers or stakeholders to answer the questions.

\subsection{Make questions, for example;}

How would you recommend our personal branding projects to your peers?
Please fill the score that could match with your own opinions, from 0 to 10 . It is noted that 0 means do not recommend any people and 10 stands for strongly recommendation.

Question: How would you recommend our personal branding projects to your peers?

\begin{tabular}{|l|l|l|l|l|l|l|l|l|l|l|}
\hline 0 & 1 & 2 & 3 & 4 & 5 & 6 & 7 & 8 & 9 & 10 \\
\hline & \multicolumn{10}{|c|}{ Detractors } \\
\hline
\end{tabular}

\subsection{Calculate NPS score}

Score 0 - 6 means that the respondents were Detractors Score 7- 8 means that the respondents were Passives Score 9-10means that the respondents were Promoters NPS $=\%$ Promoters $-\%$ Detractors

While NPS should be more than the number of 1 .

\section{CONCLUSION AND RECOMMENDATION}

Corporate brand personality could support organization in creating personal branding. Though, the procedures were not much complicate, but marketers should implement it from inside to outside of the organization, be created and done by staff. It was recommended that internal marketing strategy should be implemented to build trust and engagement among employees in the organization X.

Researcher has suggested for the future research that there should be a study about balanced score card for KPIs to measure the result of corporate brand personality projects.

\section{REFERENCES}

[1] S. Sam, "How to build your personal brand," Journal of Brand Management, vol. 1/2, pp. 74-81, 2012.

[2] Gynn Ann. (Feb. 2018). Personal VS corporate branding: Is it me or we? Content Marketing Institute. [Online]. Available: http://contentmarket.inginstitute.com/2018/02/personal-corporate-bra nding

[3] B. Brenda. (Oct. 2018). You and your company: Making the corporate brand/personal brand connection. [Online]. Available: http://www.amanet.org/training/articles/you-and-your-company.aspx

[4] S. Dan, 4 Steps to Build Your Future, New York: Kaplan, Publishing, 2010, ch. 5-8.

[5] K. L. Kevin and R. Keith, "The importance of corporate rand personality traits to a successful 21 st century business," Journal of Brand Management, vol. 14, no. 1/2, pp. 74-81, 2006.

[6] C. Chuenjit, "Geo-informatics and space technology corporate brand personality and implementation in Thailand," Review of Integrative Business and Economics Research, vol. 7, pp. 15-23, 2018.

[7] J. L. Aaker, "Dimension of brand personality," Journal of Marketing Research, vol. 34, pp. 347-356, August 1997.

[8] R. Fred, The Ultimate Question 2.0: How Net PromoteCompanies Thrive in a Customer - Driven World, Boston: Harvard Business Review Press, 2011, ch. 1.

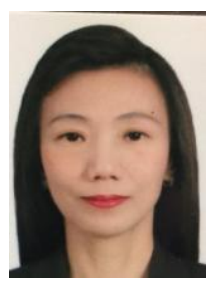

Chuenjit Changchenkit is working as a lecturer at the Faculty of Business Administration, Department of Marketing, Kasetsart University, Bangkok, Thailand. Her special expertise is on branding and brand communication. She wrote 9 textbooks in Thai version in various title, all were in marketing field. Her research papers contribute to many industry and organization, for example, real estate marketing, personal branding strategy in apparel industry, persona; branding in geo-information technology provider. 